\title{
THE EMERGENCY PRICE CONTROL ACT OF 1942: ADMINISTRATIVE PROCEDURE AND JUDICIAL REVIEW
}

\author{
Nathaniel L. Nathanson*
}

The Office of Price Administration had attained a considerable measure of maturity before the passage of the Emergency Price Control Act of 1942. ${ }^{1}$ When the Administrator took office under the statute, ${ }^{2}$ ro5 price schedules had already been issued pursuant to the authority conferred by executive order. ${ }^{3}$ Administrative procedures had been shaped in the light of the tasks at hand and the skilled personnel available; contact between the office and the courts had been practically non-existent.* In many respects the statute requires no changes in the informal procedures thus developed. It does, however, provide a pattern for the issuance, reconsideration and judicial review of the regulations and orders of the Administrator.

No fundamental innovations are required in administrative procedures preceding the establishment of price ceilings. Information may still be gathered through staff

* B.A., 1929, LL.B., I932, Yale University; S.J.D., 1933, Harvard University. Member of the Massachusetts Bar. Assistant General Counsel, Office of Price Administration; Associate Professor of Law, Northwestern University, on leave of absence. Law clerk to Circuit Judge Julian W. Mack, 1933-1934, to Justice Louis D. Brandeis, 1934-1935; Attorney, Securities and Exchange Commission, 1935-1936. Contributor to legal periodicals.

The opinions expressed herein represent only the personal views of the author and not the official vicws of the Office of Price Administration.

For considerable aid in the preparation of this article, the author is much indebted to W. Robert Ming, Jr., Senior Attorney on the staff of the Office of Price Administration and Assistant Professor of Law at Howard University.

${ }^{1}$ Pub. L. No. 42r, 77th Cong., 2d Sess. (Jan. 30, 1942). The Office of Price Administration and Civilian Supply was established by Executive Order No. 8734, dated April II, 1941, 6 FED. REc. I9I7 (194I). The name was changed to Office of Price Administration by Executive Order No. 8875, dated Aug. 28, 194I, 6 FED. REg. 4483 (I94I).

${ }^{2}$ Feb. II, I942; see 7 FED. REG. I20I (1942).

${ }^{3}$ All save Price Schedules Nos. 5, I4, 25 and 27, which had been withdrawn prior to Feb. II, 1942, were reprinted pursuant to $\$ 206$ of the Act in 7 FED. REg. $1201-1406$ (1942).

'In Pennsylvania Co. for Ins. on Lives etc. v. Cincinnati \& L. E. R. R., S. D. Ohio, Scpt. 19, 1941 (unreported), a bankruptcy court forbade a trustee to sell the debtor's property at a price above the ceiling established in a price schedule. See also Oliver Clyde Riggs, E. D. Pa., Oct. 28, I941 (unreported). In this case the Price Administrator, having been allowed to intervene, sought a court order directing the receiver not to sell machine tools at prices above those established by Price Schedule No. I. The court refused to decide the legal question raised or to postpone the sale but suggested to the receiver that the auctioneer at the beginning of the sale announce that all prices in excess of the schedulc vould be subject to the confirmation of the court. But In the Matter of the Bender Body Co., N. D. Ohio, Dec. 19, 1941 (unreported), a referee ruled that a price schedule was not applicable to a bankruptcy sale, and denied the motion of the Price Administrator to intervene. As this is written the matter is pending on a petition for review before a district judge. 
investigations and informal conferences,, 5 although formal pre-issuance hearings may be held when deemed advisable by the Administrator, and permanent price regulations must now be accompanied by statements of the considerations involved in their issuance. $^{6}$ More far-reaching changes in administrative procedure are indicated by Section 203 of the Act, which provides that after the issuance of a regulation or order under Section 2, formal protests may be filed with the Administator, who, if a protest is denied in whole or in part, must accompany the denial with an opinion indicating the grounds for such action. ${ }^{7}$ The method of judicial review is provided by Section 204, which establishes the Emergency Court of Appeals and gives it exclusive jurisdiction, subject to writ of certiorari from the Supreme Court, to determine the validity of regulations or orders issued under Section $2 .^{8}$

\section{I}

It is noteworthy that, during the consideration of the various price control bills, Congress squarely rejected the proposition that formal hearings be required before the issuance of price regulations. ${ }^{9}$ The entire legislative history indicates recognition

'In addition, the Act, $\$ 202$, confers on the Administrator power to compel the production of information by the issuance of subpenas, by regulations or orders, or by requiring reports.

- To provide the flexibility necessary to deal with the complicated problem of price control the Administrator is authorized to issue temporary maximum price regulations without any statements of considerations. Such regulations may be issued whenever, in his judgment, such action is necessary to effectuate the purposes of the Act and may be effective for not more than 60 days. Prices fixed must be those prevailing within five days prior to the issuance of the regulation. \$2(a). See, e.g., "Temporary Maximum Price Regulation No. 5, Mattresses, Springs, Studio Couches and Metal Beds and Cots," 7 FED. REg. I647 (rg42).

${ }^{7}$ On Feb. 12, 1942, the Administrator issued Office of Price Administration Procedural Regulation No. I-Procedure for the Issuance, Protest, and Amendment of Maximum Price Regulations (hereinafter cited as "Proced. Reg. No. I"). 7 FED. REG. 97 I-975 (I942). Procedural regulations for administration of rent control and for industry committees have not yet been issued.

${ }^{8}$ Section 2 authorizes the Administrator to issue regulations or orders fixing maximum prices or maximum rents. He is also empowered to regulate or prohibit speculative or manipulative practices, including changes in form or quality, hoarding, and renting and leasing practices, which, in his judgment, are equivalent to or likely to result in price or rent increases. Price schedules issued under the authority of the Executive Order No. 8734, prior to the date on which the Price Administrator took office under the statute, are, by the provisions of $\$ 206$ of the Act, given the same effect as if issued under the authority of \$2. They are also made subject to the protest procedure and to the exclusive jurisdiction of the Emergency Court of Appeals. Hereafter when reference is made to regulations or orders issued under $\$ 2$, it is to be understood that such price schedules are included. Since the passage of the Act, the Court of Common Pleas for Lucas County, Ohio has held that a price schedule effective under $\$ 206$ partly superseded a state statute requiring sales of municipal property to be to the highest bidder. Rosenblatt v. City of Toledo, (in Equity) Decision No. 159983 , April 6, 1942.

${ }^{\circ}$ 'The provisions of the bill reported by the House Banking and Currency Committee were virtually identical in this respect with the provisions of the Act. See H. R. Rep. No. 1409, 77th Cong., Ist Sess. (r94I) 10-12 (hereinafter cited as "House Report"); H. R. 5990, 77th Cong., Ist Sess. (I94X). See also Sen. Comm. Print, Hearings before Sen. Committee on Banking and Currency on $H$. $R$. 5990, 77th Cong., Ist Sess. (I94I) 72-105 (hereinafter cited as "Senate Hearings"). The first bill passed by the House authorized the issuance of price regulations by the Administrator without prior hearing, followed by opportunity for full hearing before an administrative Board of Review while the regulations remained in effect. H. R. 5990 (in the Senate), 77th Cong., Ist Sess. (I94r). The Senate rejected this. The proposal of Senator Taft to require hearings prior to the issuance of price regulations but authorizing temporary regulations without prior hearings to remain in effect for not more than sixty days was never brought to a vote. This device would have been totally ineffective for in many cases formal hearings could not have been completed in the time allowed. The Act does provide that the Administrator should, when practicable, consult with representative members of the industry prior to the issuance of a regulation or order 
of the fact that, in a war economy, effective price control cannot wait upon formal hearings. ${ }^{10}$ Immediate action often becomes necessary because of sudden changes, wrought by governmental decree or fortunes of war, in conditions of supply or demand. Too often prolonged consideration of contemplated action would encourage speculative activities and render eventual control all the more difficult. As indicated by the provision authorizing temporary maximum price regulations, ${ }^{11}$ Congress recognized that even the statutory requirements with respect to statements of considerations accompanying the issuance of permanent price regulations would be too cumbersome to meet emergency situations. ${ }^{12}$

The omission of hearings before the issuance of price regulations seems to raise no serious constitutional difficulties, even in the absence of the peculiar considerations applicable to war-time legislation. In terms of the familiar dichotomy between quasilegislative and quasi-judicial action, it is clear that price regulations under Section 2 are quasi-legislative and therefore that notice and hearing are not prerequisite to their issuance. ${ }^{13}$ This view is underscored by the provision in Section 2 (a) of the statute that "As used in the foregoing provisions of this subsection, the term 'regulation or order' means a regulation or order of general applicability and effect."14

under \$2. This practice was generally followed before the enactment of the statute. After a maximum price is established the Administrator is required to appoint an industry advisory committec, if requested to do so by a substantial portion of the industry. This committee is authorized to make recommendations to the Administrator.

${ }^{10}$ Sce e.g., House Report 9-10: "The procedure governing the preparation and issuance of substantive regulations and orders prescribing ceilings or regulating practices has necessarily been adapted to the nature of the powers granted, which involves a broad delegation of legislative power, to the fact that such regulations will apply to large numbers of persons, and to practical considerations, such as the necessity for immediate action to check rapidly rising prices and the importance of avoiding speculative disturbances of the market pending the determination of a price ceiling."

${ }^{11}$ Act, $\$ 2(a)$. See note 6 , supra.

${ }^{12}$ See SEN. Rep. No. 93I, 77th Cong., 2d Sess. (1942) I5 (hereinafter cited as "Senate Report"). "The authority to issue regulations temporarily freezing prices is necessary principally in order to enable the Administrator to meet particular emergency situations as they arise. The Administrator is thereby given sixty days to make such studies and investigations as will enable him to issuc permanent regulations."

${ }^{13}$ See Bi-Metallic Investment Co. v. Colorado, 239 U. S. 441, 445 (1915). "Where a rule of conduct applies to more than a few people it is impracticable that everyone should have a direct voice in its adoption. The Constitution does not require all public acts to be done in town mecting or an assembly of the whole. General statutes within the state power are passed that affect the person or property of individuals, sometimes to the point of ruin, without giving them a chance to be heard. Their rights are protected in the only way that they can be in a complex society, by their power, immediate or remote, over those who make the rule." See also Buttfield v. Stranahan, 192 U. S. 470 (1904); Norwegian Nitrogen Products Co. v. U. S., 288 U. S. 294 (1933); Highland Farms Dairy, Inc. v. Agnew, 16 F. Supp. 575 (E. D. Va. 1936), aff'd, 300 U. S. 608 (1937); State ex. rel. State Board of Milk Control v. Newark Milk Co., II8 N. J. Eq. 504, I79 Atl. II6 (1935); Spokane Hotel Co. v. Younger, I13 Wash. 359, 194 Pac. 595 (1920); $c$. Colteryahn Sanitary Dairy Co. v. Milk Control Commission of Pennsylvania, 332 Pa. 15, I A. (2d) 775 (I938), where the statute provided for a pre-issuance hearing. Generally, sce Hankins, The Necessity for Administrative Notice and Hearing (1940) 25 IowA L. REv. 457.

14 It is clear that there is no requirement that regulations or orders be uniform in their application or effect. See $\$ 2$ (c) which provides that: "Any regulation or order under this section . . . may contain such classifications and differentiations, and may provide for such adjustments and reasonable exccptions, as in the judgment of the Administrator are necessary or proper in order to effectuate the purposes of this Act." Such adjustments and exceptions may be provided for specifically in the price regulations, or in terms of general classifications to be applied by order granting or denying pecitions for adjustment and exception under the latter procedure. Such orders are subject to the protest procedure. Proced. Reg. No.

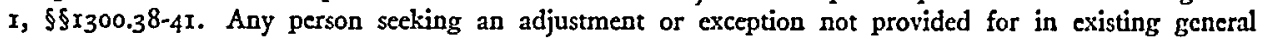


More substantial legal problems are presented by the provisions in Section 203 of the Act establishing the protest procedure. This section authorizes any person subject to any provision of a regulation or order issued under Section 2, or of a price schedule effective under Section 206, ${ }^{15}$ "to file a protest specifically setting forth objections to any such provision and affidavits or other written evidence in support of such objections." ( $\$ 203(a))$ Within a period specified in the statute, ${ }^{16}$ the Administrator must either grant or deny the protest, notice it for hearing or provide an opportunity to present further evidence in connection therewith. ${ }^{17}$ If the Administrator denies the protest he must "inform the protestant of the grounds upon which such decision is based and of any economic data and other facts of which the Administrator has taken official notice." This section also provides that the Administrator may take "official notice of economic data and other facts, including facts found by him as a result of action taken under section $202 "(\$ 203(\mathrm{~b}))$; and that he may limit protest proceedings to the "filing of affidavits, or other written evidence, and the filing of briefs." $(\$ 203(c))$

The protest proceedings may be regarded as serving two separate functions. On the one hand, they provide the Administrator with the opportunity to reconsider the regulation or order under attack and to amend or withdraw it. ${ }^{18}$ In addition, they provide the basic record for judicial consideration of the validity of the regulation or order in the Emergency Court of Appeals. Insofar as the protest proceedings are

classifications, may file a petition for amendment of any price regulation to which he is subject, or which affects him. In addition, any person subject to any provision of a price regulation may file a petition for amendment if he has failed to file a proper protest within the time specified in the statute. Moreover, any person affected by a maximum price regulation, but not subject thereto, may petition for amendment if he desires modification thereof. Proced. Reg. No. 1 , $\$ 1300.35$. Rulings on petitions for amendment are not subject to the protest procedure.

${ }^{10}$ See Proced. Reg. No. I, $\$ 1300.9$ : "A person is, for the purposes of this Regulation, [\$\$I300.I1300.56 incl.] subject to a provision of a maximum price regulation only if such provision prohibits or requires action by him."

"Whenever necessary or appropriate for the full and expeditious determination of common questions raised by two or more protests the Administrator may consolidate such protests." Proced. Reg. No. I, $\$ 1300.22$.

10 The Administrator must dispose of protests, "Within a reasonable time after the filing of any protest under this subsection, but in no event more than thirty days after such filing or ninety days after the issuance of the regulation or order . . . in respect of which the protest is filed, whichever occurs later, ...." \$203(a).

${ }^{17}$ By the provisions of Proced. Reg. No. I, $\S_{3} 300 . I 7$, protests, affidavits and briefs submitted therewith may be amended within a period of sixty days after the issuance of the maximum price regulation attacked, or, in the case of a protest properly filed more than sixty days after the issuance of such regulation, within fifteen days after such protest is filed. After the time prescribed, amendment or a presentation of further evidence is allowed only when, in the judgment of the Administrator, such action will not unduly delay the completion of the protest proceedings. However, no amendment adding a new ground of protest is permitted.

${ }^{28}$ A regulation, order or price schedule may be modified or rescinded by the Administrator even after the filing of a complaint in the Emergency Court of Appeals. \$204(a). Cf. Ford Motor Co. v. N. L. R. B., 305 U. S. 364 (1939), holding that in the absence of statutory provision to the contrary the jurisdiction of the reviewing court attached when the transcript was filed and that the agency had no absolute right to withdraw its petition for enforcement but permitting such withdrawal as a matter of judicial discretion. The Court distinguished In re N. L. R. B., 304 U. S. 486 (r938), where the agency had been permitted to withdraw its order after a petition for review had been filed, on the ground that in that case the transcript had not been sent to the Circuit Court of Appeals before the order was withdrawn. 
designed for the purpose of administrative reconsideration, they are as much quasilegislative in character as pre-issuance hearings, and, being granted as a matter of statutory rather than constitutional right, must be taken subject to statutory conditions. However, since the protest record is also the primary record for judicial determination of the validity of the regulation or order, it may be suggested that the protest procedure must meet the standards applicable to quasi-judicial administrative proceedings. Under this approach, the principal problems that may be presented are the extent to which written evidence may be substituted for oral hearing, and official notice for more orthodox methods of proof.

Administrative proceedings confined to written evidence and briefs are, of course, no novelty in American law. ${ }^{19}$ However, such proceedings afford no opportunity for cross-examination of witnesses; and there are some dicta of the United States Supreme Court to the effect that the denial of the right to cross-examine is a denial of procedural due process. ${ }^{20}$ Those expressions have invariably occurred in cases where an administrative agency has denied to a party the opportunity of knowing and rebutting the evidence upon which the agency relied.21 Many other cases have recognized that the essence of fair hearing is not the right to cross-examine but the right to have adequate opportunity for rebuttal. ${ }^{22}$ The experience of other administrative agencies indicates that in dealing with complicated economic data the best method of exploring the facts is frequently not the oral examination and cross-examination of witnesses but the exchange of verified written evidence. ${ }^{23}$ The apparent intention of the

\footnotetext{
${ }^{29}$ Perhaps the most familiar example is the shortened procedure of the Interstate Commerce Commission used, with the consent of the parties, to dispose of formal complaints by shippers. The Pcrishable Agricultural Commodities Act of 1930,46 STAT. 534 (1930), 7 U. S. C. $\$ 499$ (f)(c), provides that in reparations cases written evidence, exclusively, shall be used in cases wherein the amount claimed as damages does not exceed \$50o. Above that amount consent of the parties to this procedure is necessary. One of the most unusual examples is the use of this procedure by the National Railroad Adjustment Board in adjudication of contract rights. Decision is based on materials in the files, the written submissions of carrier and employee groups, and the "written oral argument." See Report of the AtrorNey GenernL's Committee on Administrative Procedure, Sen. Doc. No. 8, 77th Cong., ist Sess. (1941) 404-410, for a full discussion of these and other illustrations.

${ }_{20}$ See Interstate Commerce Comm'n v. Louisville \& Nashville R. R., 227 U. S. 88, 93 (1913); Lloyd Sabaudo S. A. v. Elting, 287 U. S. 329, 339-340 (1932).

22 See the Report of the Secretary of Labor's Commitien on Administrative Procedure (Dimock, Hart and McIntire), The Immigration and Naturalization Service (1940) 45, and cases there cited. See also Van Vleck, The Adamnistrative Control of Aliens (1932) 165-170; Brown, Public Service Commission Procedure (1938) 87 U. of PA. L. REv. 139, 153-154. Brown points out that most of these decisions declare that the right of hearing includes the right to cross-examine witnesses without any serious consideration of the problem. Cf. Powhatan Mining Co. v. Ickes, I 8 F. (2d) 105 (C. C. A. 6th, 194I). In that case the Bituminous Coal Division relied on a statutory requirement of "confidential" treatment to justify its refusal to disclose the source of information tabulated for the record. The court held that this denied a "fair hearing" in that cross-examination was prevented. Actually, the real objection to the procedure was that it prevented the company from meeting or explaining this evidence. A "fair hearing" was denied because of the lack of opportunity for rebuttal.

${ }^{22}$ See Low Wah Suey v. Backus, 225 U. S. 460, 471-472 (1912); Pacific Livestock Co. v. Oregon Water Board, 241 U. S. 440, 453 (I916); U. S. v. Los Angeles R. R., 273 U. S. 299, 312-313 (1927); Crowell v. Benson, 285 U. S. 22, 48 (1932); Ex parte Hidekuni Iwata, 219 Fed. 610, 6r3 (S. D. Calif. 1915), aff'd per. cur., 244 U. S. 643 (1917).

${ }^{3}$ See Report of the AtTorney Generaz's Commitien on Administrattve Procedure, supra note 19, 404-410. See also Brown, supra note 21, making an excellent argument for the adoption of this type of procedure in public utility rate cases and carefully analyzing the arguments pro and con.
} 
Emergency Price Control Act and the procedural regulations of the Administrator is to encourage the exchange of written evidence wherever this is administratively feasible and where it will not interfere with the essence of a fair hearing. ${ }^{24}$ Such a policy is essential to the success of the emergency price control program. Under present conditions it would be virtually impossible to assemble a staff of competent experts large enough both to participate in lengthy oral hearings, and also to accomplish the investigations and study necessarily incident to the issuance and continuous reconsideration of price regulations.

The procedural regulations issued by the Administrator afford the mechanism for determining when oral testimony or some form of compulsory process is essential to a fair hearing. They provide that the protestant must file, in conjunction with his protest, "affidavits setting forth in full all the evidence, the presentation of which is subject to the control of the protestant, upon which the protestant relies in support of the facts alleged in the protest"25 and in addition, that he may file a statement in "affidavit form setting forth in detail the nature and source of any further evidence not subject to his control, upon which he believes he can rely in support of the facts alleged in his protest."26 On the basis of these statements the Administrator will determine whether full oral hearing or some method of compulsory process should be afforded.27 The Administrator may also incorporate in the protest record such written evidence, in the form of affidavits, or otherwise as he deems appropriate to support the regulation under attack. ${ }^{28}$ Copies of any such written evidence incorporated in the record without an oral hearing must be served upon the protestant and he must be given a reasonable opportunity to present evidence in rebuttal. ${ }^{29}$

3t See Act, §203; Proced. Reg. No. I, §§1300.15, I300.21.

${ }^{28}$ Proced. Reg. No. I, \$1300.15(a). $\quad{ }^{26}$ Proced. Reg. No. I, \$1300.15(b).

${ }^{27}$ Proced. Reg. No. I, $\$ 1300.23$. Due process does not require that parties to an administrative proceeding have the aid of compulsory process. See Low Wah Suey v. Backus, 225 U. S. 460 (rgI2), upholding a deportation statute which did not authorize the issuance of process to compel the attendance of witnesses for the alien. See also Missouri ex. rel. Hurwitz v. North, 27 I U. S. 40 (x926), discussed in Freund, Due Process in the Revocation of Licenses (1927) 21 ILL. L. Rev. 493; and Brinkley v. Hassig, 130 Kan. 874, 289 Pac. 64 (1930). The only case to the contrary is Jewell v. McCann, 95 Ohio St. 19r, II6 N. E. 42 ( 1917 ), announcing the decision per curvam but referring to no authorities and giving no reasons for the result.

If provision is made for the issuance of subpenas, a party to an administrative proceeding is not entitled to procure their issuance as a matter of right. See generally, Note, Subpoenas and Due Process in Administrative Hearings (r940) 53 HARv. L. REv. 842. Defendants are not universally entitled to the issuance of subpenas as a matter of right in either criminal or civil proceedings. See Goldsby v. U. S., I6o U. S. 70 (I895); Owens v. State, I69 Miss. I4I, I52 So. 65I (I934); Note (I922) 2I A. L. R. 335, supplemented (I927) 48 A. L. R. 947. But see Coney Island Dairy Products Corp. v. Baldwin, 243 App. Div. $178,276 \mathrm{~N}$. Y. Supp. 682 (1935), annulling a revocation of a milk dealer's license solely on account of the commissioner's refusal to furnish subpenas ordering the appearance of the witnesses on the dealer's behalf. This decision is clearly inconsistent with the rule in judicial proceedings. It is common practice for administrative agencies to exercise discretion in the issuance of subpenas. See e.g., SEC, Rules of Practice, Rule V (f); NLRB, Rules and Regulations, Art. II, \$2r. These rules have been judicially approved. See Inland Steel Co. v. N. L. R. B., rog F. (2d) 9 (C. C. A. 7th, r940); North Whittier Heights Citrus Ass'n v. N. L. R. B., $x 09$ F. (2d) 76 (C. C. A. 9th, r940), cert. denied, 3 ro U. S. 632 (1940). However, if the refusal of subpenas results in depriving the party of significant evidence, the court, on review, may remand for the taking of testimony. See N. L. R. B. v. Ed. Friedrich, Inc., II6 F. (2d) 888 (C. C. A. 5th, 1940).

${ }^{28}$ Proced. Reg. No. I, $\$ \$ 1300.20$ and $1300.21 . \quad{ }^{28} \mathrm{Ibid}$. 
Thus the procedural regulations carefully safeguard the right of the protestant to be apprised of, and to have an opportunity to meet, the evidence upon which the Administrator relies.

A substantial part of the record upon which the Administrator relies to support any regulation may be materials of which he takes "official notice." 30 It is clear that in using the term "official notice" the statute contemplates something more than those matters of common knowledge which ordinarily come within the scope of judicial notice. This is made explicit by the provision that the "Administrator may take offcial notice of economic data and other facts, including facts found by him as a result of action under Section 202." ${ }^{31}$ ( $\left.\$ 203(b)\right)$ Thus the Administrator may incorporate in the record of the protest proceedings the result of studies and investigations made by his staff, as well as reports or other information filed with the Office of Price Administration in accordance with requests or requirements issued under Section 202. ${ }^{32}$ This is not an entirely novel use of the concept of "official notice." Other administrative agencies have adopted the practice of incorporating into the record of particular proceedings reports filed in accordance with general information gathering requirements, or facts established in other proceedings. ${ }^{33}$ The further development of this practice is quite generally regarded as desirable, especially where the

\footnotetext{
${ }^{30}$ See generally, on the subject of "official notice," Gellhorn, Official Notice in Administrative Adjudicttion (194I) 20 TEx. L. REv. I3I; Brown, supra note 21; Faris, Judicial Notice by Administrative Bodies (1928) 4 IND. L. J. I67; Note, Judicial Notice by Administrative Tribunals (1934) 44 YaLE L. J. 355.

${ }^{31}$ By $\$ 202$ of the Act the Administrator is authorized to make such studies and investigations and to obtain such information as he deems necessary or proper to assist him in the performance of his duties. $\mathrm{He}$ is empowered to issue subpenas requiring appearance and testimony of any person, or the production of any documents. On application of the Administrator, the district courts may order compliance with these subpenas and punish failure to comply with such orders as contempt of the court. In addition, the Administrator may, by regulation, order or subpena require any person in the business of dealing in any commodity or in the business of renting housing accommodations to furnish information, or keep records and make reports. These investigatory powers are not confined in their use to protest proceedings. Sce \$5 of the Lever Act, 40 STAT. 276 (r917), which also provided for extensive investigatory powers. The necessity for such provisions as an aid to effective price control is aptly described in U. S. v. Mulligan, 268 Fed. 893,897 (N. D. N. Y. 1920). See also Bituminous Coal Act of 1937, 50 Srat. 77, 88, 89 (1937), 15 U. S. C. A. $\$ \$ 833,840,844$; Fair Labor Standards Act, 52 STAT. 1065, 1066 (1938) 29 U. S. C. A. $\$ \$ 209$, 2II. Exercise of these powers would appear to create no serious constitutional problems. See Electric Bond \& Share Co. v. Securities Exchange Comm'n, 303 U. S. 4rg (r938); American Tel. \& Tel. Co. v. U. S. 299 U. S. 232 (1936); Smith v. Interstate Commerce Comm'n, 245 U. S. 33 (1917); cf. Harriman v. Interstate Commerce Comm'n, 2 II U. S. 407 (1908); Federal Trade Comm'n v. American Tobacco Co,, 264 U. S. 298 (1924).

${ }^{32}$ Section 202(h) prohibits the Administrator from publishing or disclosing any information obtaincd under the Act which he deems confidential, or as to which a request for confidential treatment is made by the person furnishing the information, unless the Administrator determines that the withholding thereof is contrary to the interest of national defense and security. Clearly the exception would authorize disclosure of "confidential information" if necessary to provide a "fair hearing." Cf. Powhatan Mining Co. v. Ickes, I 8 F. (2d) ro5 (C. C. A. 6th, r94r), reaching a similar result despite a flat statutory prohibition of disclosure. See also In re Culhane, 269 Mich. 68, 256 N. W. 807 (1934); Werner v. Crippen, 245 App. Div. 363, 282 N. Y. Supp. 722 (1935); with which compare Bank of America v. Douglas, 105 F. (2d) 100 (App. D. C. r939). The same result would be reached if such information were necessary to sustain a rcgulation or order against attack as arbitrary or capricious.

${ }^{33}$ Cf. Railroad Commission v. MeDonald, 90 S. W. (2d) 581 (Tex. Civ. App. 1936); In the Matter of Consumers Power Co., 6 S. E. C. 444 (r939). See also Report of the Attonney Generar's Comauttee on Admistrative Procedure, supta note 19, at 398-403.
} 
matter involved is complicated economic data, not easily susceptible of proof by ordinary methods. ${ }^{34}$

Constitutional limitations upon the use of "official notice" are essentially similar to the restrictions imposed upon the use of written evidence. The courts have disapproved of this device only where it has resulted in a failure by the administrative agency to give timely advice to the parties as to the information upon which the administrative action is based. ${ }^{35}$ The procedural regulations and the statute both provide adequate protection against this danger. In most, if not all, instances, facts of which the Administrator takes "official notice" will be included in the statement of considerations or in supplementary statements incorporated in the record of the protest proceedings and served upon the parties, with full opportunity for rebuttal. If, in the opinion disposing of a protest, the Administrator should refer for the first time to additional facts as a basis for his action, the provisions with regard to the admissibility of new evidence either before the Administrator or the Emergency Court of Appeals would prevent this procedure from amounting to a denial of due process. ${ }^{36}$

Conceivably other constitutional objections to particular protest proceedings may

as See id. at 7I-73, and articles cited, supra note 30 . See Gellhorn, Federal. Admimistrative Pro-
Cezpings (r94I) 82-99.
${ }^{85}$ See U. S. and Interstate Commerce Comm'n v. Abilene 8 Southern R. R., 265 U. S. 274 (I924), where the Court set aside an order of the Interstate Commerce Commission. At the Commission hearing the examiner had announced that "No doubt it will be necessary to refer to the annual reports of all these carriers." This was the only notification to the carriers of the intention of the Commission to rely on certain facts in the annual reports. At p. 289 the Court said, "The objection to the use of the data contained in the annual reports is not lack of authenticity or untrustworthiness. It is that the carriers were left without notice of the evidence with which they were, in fact, confronted, as later disclosed by the finding made. The requirement that in an adversary proceeding specific reference be made, is essential to the preservation of the substantial rights of the parties."

Similarly in Ohio Bell Telephone Co. v. Public Utilities Comm'n, 301 U. S. 292, 302-303 (1937), the Court condemned a rate order issued by the Commission after consideration of certain standard price indices not included in the record, saying, "When price lists or trade journals or even government reports are put in evidence upon a trial, the party against whom they are offered may see the evidence or hear it and parry its effect. Even if they are copied in the findings without preliminary proof, there is at least an opportunity in connection with a judicial review of the decision to challenge the deductions made from them. The opportunity is excluded here. The Commission, withholding from the record the evidential facts that it has gathered here and there, contents itself with saying that in gathering them it went to journals and tax lists, as if a judge were to tell us, 'I looked at the statistics in the Library of Congress, and they teach me thus and so.' 'This will never do if hearings and appeals are to be more than empty forms."

Neither of these cases casts any doubt on the validity of the procedure under the Price Control Act, in view of the elaborate machinery provided for notice to a protestant of all the facts on which the Administrator relies.

${ }^{30}$ Section 204 (a) of the Act provides "If application is made to the court by either party for leave to introduce additional evidence which was either offered to the Administrator and not admitted, or which could not reasonably bave been offered to the Administrator or included by the Administrator in such proceedings, and the court determines that such evidence should be admitted, the court shall order the cvidence to be presented to the Administrator. The Administrator shall promptly receive the same, and such other evidence as he deems necessary or proper, and thereupon he shall certify and file with the court a transcript thereof and any modification made in the regulation, order, or price schedule as a result thereof; except that on request by the Administrator, any such evidence shall be presented directly to the court." This would enable a protestant who learned that evidence was relied upon by the Administrator only from the opinion issued on denial of the protest to rcbut such evidence if he chose. 
be raised on the basis of the Morgan cases. ${ }^{37}$ Reference may be made, for example, to the doctrine that the Government's position must be fully disclosed in advance of administrative decision ${ }^{38}$ or to the doctrine that "the one who decides must hear." ${ }^{30}$ Full discussion of such objections must of necessity await the particular proceedings in which they arise. Suffice it to say here that the statutory provisions and the procedural regulations indicate that the essential requirements of the Morgan cases will be satisfied. However, it may also be pointed out that logically those requirements have little, if any, application to protest proceedings, since they are not "adversary" or "quasi-judicial" in the sense that those terms were used by Chief Justice Hughes in the first and second Morgan cases.40 In so far as they have an administrative significance, they are designed for reconsideration of the original regulation and are as much legislative in character as pre-issuance hearings. The requirements of procedural due process are applicable only to the extent that the record in the protest proceedings is also the record on which the Emergency Court must determine the validity of the regulation. For this purpose, as elaborated hereafter, the provisions

${ }^{37}$ Morgan v. U. S., 298 U. S. 468 (1936), 304 U. S. I (1938), rehearing denicd, 304 U. S. 23 (1938), 307 U. S. 183 (r939), 313 U. S. 409 (r94I).

${ }^{38}$ It has already been demonstrated that the procedure outlined by the statute and regulations provides for ample notice of the evidence relied upon by the Administrator in issuing any regulations or orders under $\$_{2}$, or in acting on any protest.

${ }^{39}$ The doctrine that "the one who decides must hear" cannot be applied literally. It docs not preclude use of assistants by administrative officers. See Morgan v. U. S., 298 U. S. 468 , 48r (1936), and id. $3^{13}$ U. S. 409,422 (194I). Cf. U. S. Trust Co. v. Blake, 234 N. Y. 273,137 N. E. 327 (I922). Whether this requirement bas been complied with can only be determined on the basis of the facts in a particular case.

Of considerable importance in this connection is the authorization to the Administrator of the general power of sub-delegation. Section 20I(b) provides that the Administrator "or any duly authorized representative may exercise any or all of his powers in any place." It is clear from the legislative history of the Act that this was intended as a grant of authority to sub-delegate. See Senate Report 20, where in commenting on \$20I, it is said, "He [the Administrator] may perform his duties through such employees or agencies by delegating to them any of the powers given to him by the bill." Despite a similarity in language, differences in legislative intent, as evidenced in the Congressional history, serve to distinguish the Emergency Price Control Act from the Fair Labor Standards Act, 52 STAT. ro6o (1938), 29 U. S. C. A. \$201. Therefore, the decision in Cudahy Packing Co. of Louisiana v. Holland, 62 Sup. Ct. 651 (x942), holding invalid a delegation by the Administrator under that Act, of the power to sign and issuc subpenas to a regional director, is not controlling so far as construction of the Emergency Price Control Act is concerned. There seems to be little doubt of the validity of a legislative grant of a general power of sub-delegation. Generally, see Gellhorn, Administrattve Law-Cases and Conmments (1940) 315-323.

${ }^{40} 298$ U. S. 468 (1936); 304 U. S. I (1938). Whether the hearing on a protest proceeding is oral or written it will take place after the issuance of a general regulation. The general applicability of regulations or orders issued under $\$ 2$ of the Act demonstrates that they are not directed against specific partics as were the proceedings in the Morgan cases. This distinction may require qualification in instances where general classifications contained in price regulations are being applied to particular individuals. Sce notc I4, supra.

A further distinction is indicated by the statement of the Court in the first Morgan case that, "Congress has required the Secretary to determine, as a condition of his action, that the existing rates are or will be 'unjust, unreasonable, or discriminatory.' If and when he so finds, he may 'determine and prescribe' what shall be the just and reasonable rate, or the maximum or minimum rate, thereafter to be charged. That duty is widely different from ordinary executive action. It is a duty which carries with it fundamental procedural requirements." 298 U. S. $468,479-480$ (1936). No such requirement is imposed by this act. The statement of considerations which must accompany any regulation or order issued under $\$ 2$ must be distinguished from the "findings of fact" frequently required of quasi-judicial agencies. The former is intended to show the basis for the administrative action in the light of the standards set up in $\$ \S \mathrm{I}$ and 2 , but no particular facts need be found to exist to justify the imposition of a maximum price. 
authorizing the court to require the taking of additional evidence and giving it ultimate control over the record, are sufficient to assure the protestant of an adequate judicial hearing on the validity of the regulations.

\section{II}

The provisions for judicial review under the statute are to be found in Section 204, which creates the Emergency Court of Appeals and gives it exclusive jurisdiction, subject to writ of certiorari from the Supreme Court, to determine the validity of Section 2 regulations and orders. ${ }^{41}$ This court is to consist of three or more federal district or circuit judges, designated by the Chief Justice of the United States. (\$204(c)) The Emergency Court is authorized to sit in divisions of three or more members and each division may render judgment as the judgment of the court. At present writing, Chief Justice Stone has already designated a court of three judges, who will presumably convene for the purpose of hearing particular cases as the necessity arises. ${ }^{42}$

The Act provides that "any person who is aggrieved" ${ }^{43}$ by the denial or partial denial of his protest may, within thirty days after such denial, file a complaint with the Emergency Court of Appeals, ... praying that the regulation, order or price schedule protested be enjoined or set aside in whole or in part." ( $\$ 204(a))$ When this complaint is served upon the Administrator, he must certify and file with the court a transcript of those portions of the protest record material to the complaint. ${ }^{44}$ The court is directed to consider only objections advanced in the protest and only evidence contained in the transcript. ${ }^{45}$ (\$204(a)) However, the court may also require the

\footnotetext{
1I The exclusive jurisdiction of the Emergency Court of Appeals does not extend to regulations or orders of the Administrator issued under the provisions of $\$ 202$. The protest procedure is expressly limited to regulations or orders under $\$ 2$ and price schedules effective under the provisions of $\$ 206$. $\$ 203(\mathrm{a})$. The jurisdiction of the Emergency Court of Appeals is specifically limited to consideration of complaints by persons aggrieved by denial of a protest.

${ }^{2}$ On March 2, I942, Chief Justice Stone named the following: Justice Fred M. Vinson (App. D. C.), Chicf Judge; Judge Calvert Magruder (C. C. A. Ist); Judge Albert B. Maris (C. C. A. 3rd). The Chief Judge is authorized to divide the court into divisions. The court is empowered to prescribe its own rules of procedure, hire a clerk and to hold sessions at such places as it may select. $\$ 204$ (c).

43 The class of persons entitled to judicial review of administrative action has been similarly limited to those "aggrieved" in the Federal Communications Act, 48 STAT. I093 (1934), 47 U. S. C. A. $\$ 402$ (b) (2), and in the Natural Gas Act, 52 STAT. 821 (1938), I5 U. S. C. A. \$717. These provisions have been judicially construed to require one who sought to attack administrative action to show that it interfered with some substantial right or interest accruing to him. See Federal Communications Comm'n v. Sanders Bros. Radio Station, 309 U. S. 470 (1940); Yankee Network v. Federal Communications Comm'n, 107 F. (2d) 212, 215 (App. D. C., 1939); Arkansas-Louisiana Gas Co. v. Federal Power Comm'n, II3 F. (2d) $28 \mathrm{r}, 284$ (C. C. A. 5 th, 1940). Inasmuch as a protest must precede complaint to the Emergency Court of Appeals, a further limitation on the class of persons entitled to judicial review is found in the administrative interpretation of $\$ 203(a)$. In Proced. Reg. No. I, $\$ 1300.9$, persons entitled to file protests are defined as those of whom a regulation requires or prohibits action.

"See Proced. Reg. No. I, §1300.34, 7 FED. REg. 97X, 974 (I942): "The transcript for judicial review shall include: (a) the maximum price regulation against a provision of which the protest was filed; (b) the statement of considerations accompanying such regulation; (c) the protest; (d) a statement setting forth, as far as practicable, the economic data and other facts of which the Administrator has taken official notice; and (e) such other portions of the proceedings in connection with the protest as are material under the complaint."

"See Senate Hearings $25 x$.
} 
inclusion in the record of evidence which was rejected by the Administrator and evidence which could not reasonably have been offered to the Administrator or included by him in the transcript. Such evidence may be taken by the Administrator in connection with reconsideration of the protest, or at his request, may be presented directly to the court. ${ }^{46}$ In disposing of the case, the court may dismiss the complaint, set aside the regulation, order or price schedule, in whole or in part, or remand the proceeding to the Administrator. (\$204(d))

Although the proceeding in the Emergency Court is in form an original one, it is in substance a review of administrative action. In this respect the procedure is fundamentally similar to review of several other federal administrative agencies through injunction suits in the district courts. ${ }^{47}$ Since a fundamental purpose of the protest procedure is to provide an opportunity for administrative reconsideration of the regulation, order or price schedule, the requirement that the court consider only objections presented to the Administrator merely codifies the usual rule of exhaustion of administrative remedies. ${ }^{48}$ The provision that the record before the court should consist primarily of the record before the Administrator is also clearly valid, for it can hardly be contended that a judicial trial de novo is a constitutional requisite for the review of regulations or orders issued under the Act. ${ }^{49}$

The Act formulates a standard for the proper scope of judicial review by providing that "No ... regulation, order, or price schedule shall be enjoined or set aside, in

${ }^{16}$ See note 36 , supra.

${ }^{47}$ Compare the practice under the Urgent Deficiencies Act, where the practice of limiting the record on review to that made before the administrative agency has been generally followed without express statutory requirements. See Manufacturers Railway v. U. S., 246 U. S. 457, 470, 488, 490 (1918); St. Joseph Stock Yards Co. v. U. S., 298 U. S. 38 (I936); Morgan v. U. S., 298 U. S. 468 (1936); Shiclds v. Utah Idaho Central R. R, 305 U. S. 177 (1938). But sce Baltimore \& Ohio R. R. v. U. S., 298 U. S. 349 (1936). Compare judicial review of orders of the Secretary of Agriculture under the Packers and Stockyards Act, 42 STAT. 168 (I92I), 7 U. S. C. \$2I7, 49 STAT. 649 (1935), 7 U. S. C. A. \$2I8(c); and of certain orders of the Federal Communications Commission under the Communications Act of "1934, 48 Stat. x093, 47 U. S. C. A. 5402 (a). See Report of the ATtornex General's Committee on Administrative Procedure, supra note 19 , at 83 .

48 "(It is a) long settled rule of judicial administration that no one is entitled to judicial relicf for a supposed or threatened injury until the prescribed administrative remedy has been exhausted." Myers v. Bethlehem Shipbuilding Corp., 303 U. S. 4I, 50-5I (1938). Statutory limitation of the issues before the Emergency Court of Appeals to those raised by the protest to the Administrator insures compliance with this fundamental requirement. See, generally, Raoul Berger, Exhaustion of Administrative Remedies (1939) 48 YALE L. J., 981; Note, Primary Jurisdiction-Effect of Administrative Remedies on the Jurisdiction -of Courts (1938) 5I HARv. L. REv. I251; Note, Administrative Action as a Prerequisite of Judicial Relief (1935) 35 CoL. L. Rev. 230; Note, The Necessity of Exhatusting Administrative Remedies before Resorting to Judicial Review (1927) 27 CoL. L. Rev. 450; (1939) 87 U. of PA. L. Rev. 475 and 609.

49 The Supreme Court has carefully limited the requirement of trials de novo to the "jurisdictional fact" situation of Crowell v. Benson, 285 U. S. 22 (1932). Despite the apparently conflicting language of that opinion with respect to the imposition of the same requirement to "constitutional facts," both earlier and later decisions show clearly that the rule has never been so applied. Even in St. Joseph Stock Yards Co. v. U. S., 298 U. S. 38 ( 1936 ), although requiring an "independent judicial determination" as to the facts in a "confiscation" case, the Court approved the procedure followed by the lower court in limiting its record to that made before the administrative agency. See also Acker v. United States, 298 U. S. 426 (I936); cf. South Chicago Coal \& Dock Co. v. Bassett, 309 U. S. 251 (1940). The "jurisdictional fact" concept would appear to have no application to proceedings under the Emergency Price Control Act so as to require the Emergency Court of Appeals to conduct trials de novo. 
whole or in part, unless the complainant establishes to the satisfaction of the court that the regulation, order or price schedule is not in accordance with law, or is arbitrary or capricious." ( $\$ 204(\mathrm{~b})$ ) This is the same standard that would be applied, in the absence of a specific statutory direction, by federal courts in reviewing quasilegislative action.50 It should be distinguished from the familiar "substantial evidence" rule, frequently employed in judicial review of administrative action of a quasi-judicial character, ${ }^{51}$ and occasionally, by statutory prescription, in review of quasi-legislative action. ${ }^{52}$ Where full adversary hearings are required prior to the issuance of administrative regulations or orders, the issue on review may properly be phrased in terms of whether there is "substantial evidence" in the record to justify the order. Under this Act, however, pre-issuance hearings are not required. Although an administrative hearing precedes denial of a protest, the proceeding in the Emergency Court of Appeals is to review the validity of the original regulation or order rather than the denial of the particular protest. ${ }^{53}$ Therefore, the Act properly places upon the protestant the burden of offering sufficient proof to overcome the presumption of validity which attaches both to legislative and quasi-legislative action. ${ }^{54}$ Clearly the Act does not contemplate the substitution of the independent judgment of the court for that of the Administrator on those questions committed by the statute to the judgment of the Administrator. Rather the function of the court is to determine whether or not the action of the Administrator was arbitrary or capricious in the light of the record before the court, or otherwise in violation of any statutory or constitutional requirements. ${ }^{55}$

${ }^{t 0}$ See American Tel. \& Tel. Co. v. U. S., 299 U. S. 232, 236-237 (1936), where in sustaining an order of the Federal Communications Commission, the Court described the proper standard as follows: "This court is not at liberty to substitute its own discretion for that of administrative officers who have kept within the bounds of their administrative powers. To show that these have been exceeded in the field of action here involved, it is not enough that the prescribed system of accounts shall appear to be unwise or burdensome or inferior to another. Error or unwisdom is not equivalent to abuse. What has been ordered must appear to be "so entirely at odds with fundamental principles of correct accounting' .. . as to be the expression of a whim rather than an exercise of judgment." Cf. Gray v. Powell, 62 Sup. Ct. 326 (I94I); and Railroad Comm'n of Texas v. Rowan \& Nichols, 310 U. S. 573 (I940), amended 3II U. S. $6 \mathrm{I}_{4}$ (1940); id. 3 II U. S. 570 (I94I). See also Swayne \& Hoyt Ltd. v. U. S., 300 U. S. 297 (1937); U. S. v. Louisville \& Nashville R. R., 235 U. S. $3 I_{4}$ (1914).

EI Securities Exchange Act of I934, 48 STAT. 90I, I5 U. S. C. $\$ 78(y)$; Federal Alcohol Administration Act, 49 STAr. 978 (1935), 27 U. S. C. A. $\$ 204(\mathrm{~h})$; Federal Power Act, 49 STAT. 860 (1935), I6 U. S. C. A. $\$ 825$ (l) (I94I). The "substantial evidence" test has been applied even in the absence of statutory requirements. See Consolidated Edison Co. v. N. L. R. B., 305 U. S. I97, 229 (I938). See also Reporr of the Attorney Generat's Committee on Administrative Procedure, supra note I9, at 89.

${ }^{2}$ Sec Fair Labor Standards Act of 1938, 52 STAT. 1065 (1938), 29 U. S. C. A. \$210; Bituminous Coal Act of 5937,50 STAt. 85 (I937), I5 U. S. C. A. $\$ 836(\mathrm{~b})$.

${ }^{53}$ Note that by the provisions of $\$_{20}$ (b) of the Act, the Emergency Court of Appeals can set aside or enjoin a regulation only if "the complainant establishes to the satisfaction of the court that the regulation, order or price schedule, is not in accordance with law, or is arbitrary or capricious."

"See South Carolina Highway Dep't v. Barnwell Brothers, 303 U. S. 177, 191 (1938), where the Court considered the nature of the judicial function in determining the validity of legislative action. See also American Tel. \& Tel. Co. v. U. S., 299 U. S. 232 (1936), applying the same test to quasi-legislative action.

ET The legislative history of the Act demonstrates clearly that this is the Congressional intent. See Senate Report 7-8, where it is said that: "Although the Court may not substitute its judgment for that of the Administrator on questions of fact, it may examine the entire record before the Administrator to determine whether he has acted in accordance with the statute, whether the procedure that he has followed 
Even as to constitutional objections that may be raised in the Emergency Court of Appeals to particular regulations or orders, the standard of review prescribed is perfectly appropriate. Any argument to the contrary could be based only upon the much criticized, and frequently ignored, Ben Avon doctrine. ${ }^{50}$ However, the Supreme Court has steadfastly refused to apply the Ben Avon rule in any save public utility rate cases where the charge of confiscation has been made. ${ }^{57}$ In the case of a general price regulation, as in the case of other general regulations, there is no comparable issue of confiscation. ${ }^{58}$ In Railroad Commission of Texas v. Rowan \& Nichols the lower court was severely criticized for making an independent determination of the merits of the claim that an oil proration order was confiscatory; in upholding the order, the Supreme Court applied exactly the same standard of review as that prescribed by the Price Control Act. ${ }^{59}$ Furthermore, the recent decision in Federal Power Commission v. Natural Gas Pipeline Company of America is authority for ignoring the Ben Avon doctrine even in public utility rate cases. There the Court, having before it an order of the Federal Power Commission challenged as confiscatory, indicated that it considered itself bound by the statutory prescription of the "substantial evidence" rule and applied that standard in sustaining the Commission's order. ${ }^{60}$ In the light of

is in accordance with accepted standards of due process of law, and whether he has exercised a reasonable judgment on questions committed to his discretion." See also Senate Hearings 251-252; House Hearings 406.

${ }^{50}$ Ohio Valley Water Co. v. Ben Avon Borough, 253 U. S. 287 (1920). The state public utility act had been construed as limiting the power of a state court on review of a rate order to an inquiry as to whether the order was a reasonable exercise of administrative discretion. Borough of Ben Avon v. Ohio Valley Water Co., 260 Pa. 289, ro3 Atl. 744 (r9r8). The Supreme Court ruled that due process required an "independent judicial determination" of both facts and law since the company claimed that the order would result in confiscation of its property. There is a tremendous amount of periodical material critical of the case. A few of the articles are: Landis, Administrative Policies and the Courts (1938) 47 Yal: L. J. 519; Freund, The Right to a Judicial Review in Rate Controversies (1921) 27 W. VA. L. Q. 207; Albertsworth, Judicial Review of Administrative Action by the Federal Supreme Court (1921) 35 Harv. L. REv. x27. See also St. Joseph Stock Yards Co. v. U. S., 298 U. S. 38 (r935), re-examining and reaffirming the doctrine of the Ben Avon case.

${ }^{57}$ See the concurring opinion in St. Joseph Stock Yard Co. v. U. S., 298 U. S. 38, 73 (1935), and cases there cited. Mr. Justice Brandeis demonstrated that the Court has followed no rigid rule in the application of the doctrine of "constitutional facts." The factors which the Court has relied upon to avoid the rule of the Ben Avon case and the decisions themselves clearly demonstrate that review of administrative action properly. is limited to determining the reasonableness of the regulation.

${ }^{38}$ See Freund, The Emergency Price Control Act of 1942: Constitutional Isstes, infra, at 83 .

${ }^{50} 3$ ro U. S. 573 (1940); amended, 3 II U. S. 6r4 (r940); id. 3 II U. S. 570 (I94I). The decision of the lower court was characterized as being "dominated by their own conception of the fairness and reasonableness of the challenged order." This, the Court said, required a "fresh reminder that courts must not substitute their notions of expediency and fairness for those which have guided the agencies to whom the formulation and execution of policy have been entrusted." 3 ro U. S. 573, 580-581. Clcarly the Court denied that there was any necessity for independent judicial determination in every case in which it is claimed that confiscation results from administrative action. In view of the fact that the doctrine of "constitutional facts" of the Ben Avon and St. Joseph Stock Yards Co. cases springs from limitations on administrative action imposed by the due process clause, differences in judicial review based on types or degrees of confiscation are illogical. Reconciliation, therefore, of the Ben Avon and Rowan \& Nichols cases seems impossible.

${ }^{60}$ See Federal Power Comm'n v. Natural Gas Pipe Line Co., 62 Sup. Ct. 736 (1942). See particularly the Court's treatment of the issue as to "Rate of Return." Id. at 747-748. The Court said: "The Commission found that ' $61 / 2$ per cent is a fair annual rate of return upon the rate base allowed, which it had characterized as 'a generous allowance.' The courts are required to accept the Commission's findings if they are supported by substantial eridence. . . . We cannot say on this record that the Commission was 
these decisions, there is no room for doubt as to the validity of the scope of review provided for regulations, orders and price schedules under the Price Control Act.

The Emergency Court has powers sufficient to correct procedural as well as substantive errors in the administration of the statute. Errors attendant upon the original issuance of the regulation or order could, of course, be asserted in the protest and again in the complaint initiating proceedings in the Emergency Court. Any alleged inadequacy in the protest proceedings could be cured by application to the court for leave to introduce additional evidence and by the exercise of the powers of the court to remand the proceedings. Errors in the protest procedure would not, however, be grounds for setting aside the regulation or order being protested. They would merely afford the basis for an order of the court setting aside the denial of the protest and directing the Administrator to proceed in accordance with the opinion of the court. ${ }^{61}$ In so doing the court could not direct the Administrator as to how he should exercise his administrative discretion, for it is clearly intended that the Emergency Court should act solely as a constitutional, rather than as a legislative or administrative, court. $^{62}$ It could, however, require the reopening and the completion of the protest proceedings so as to assure an adequate basis for judicial determination of the validity of the regulation or order under attack. ${ }^{63}$

The most significant limitations on the powers of the Emergency Court are those prohibiting it from issuing temporary injunctions and staying the effectiveness of its final judgments pending opportunity for review in the Supreme Court of the United States. ${ }^{04}$ These provisions, like the provisions for exclusive jurisdiction, are essential

bound to allow a higher rate." The order reviewed here was an interim one having been issued on the basis of the company's evidence alone. The issues, therefore, were confined to those generally characterized as "questions of law." Denial of an "independent judicial determination" of such questions is the strongest possible refutation of the doctrine of the Ben Avon case.

${ }^{01}$ The court has no power to enjoin or set aside a regulation, order or price schedule "unless the complainant establishes to the satisfaction of the court that the regulation, order, or price schedule is not in accordance with law, or is arbitrary or capricious." $\$ 204$ (b). In addition to this power, however, the court may "remand the proceedings." \$204(a). It is clear that this power may be exercised to correct procedural defects which the court should consider. See Senate Report 8.

${ }^{02}$ Section $20_{4}$ (b) provides that, "The effectiveness of a judgment of the court enjoining or setting aside, in whole or in part, any such regulation, order, or price schedule shall be postponed until the expiration of thirty days from the entry thereof, except that if a petition for a writ of certiorari is filed with the Supreme Court under subsection (d) within such thirty days, the effectiveness of such judgment shall be postponed until an order of the Supreme Court denying such petition becomes final, or until other final disposition of the case by the Supreme Court." Section 204(c) limits the power of the Emergency Court by providing that, "the court shall not have power to issue any temporary restraining order or interlocutory decree staying or restraining, in whole or in part, the effectiveness of any regulation or order issued under section 2 or any price schedule effective in accordance with the provisions of section 206."

${ }^{03}$ See Keller v. Potomac Electric Power Co., 261 U. S. 428 (r923); Federal Radio Comm'n v. General Electric Co., 28 r U. S. 464 (r930). Cf. Federal Radio Comm'n v. Nelson Bros. Bond \& Mortgage Co., 289 U. S. 266 (1933). Any other construction would create considerable doubt as to the validity of the provision for review of orders and judgments of the Emergency Court of Appeals by the Supreme Court.

${ }^{\circ 4}$ See the discussion in Federal Communications Comm'n v. Pottsville Broadcasting Co., 309 U. S. I34 (1940), of the proper relationship between an administrative agency and a reviewing court in an analogous situation. That case arose from the effort of an applicant to compel the Commission to give him separate consideration. After the original order denying his application had been set aside by the reviewing court, the agency consolidated three applications for consideration on a comparative basis. The Court held 
to the contiauity and therefore to the effectiveness of price control. If a price regulation were suspended during litigation, a final decision of the Emergency Court or of the Supreme Court sustaining its validity would be indeed a Pyrrhic victory. When the pressures of a seller's market are as great as they are today, price rises in one commodity are quickly reflected elsewhere in the economy. In the battle against inflation, ground once lost can seldom be regained. If preliminary injunctions were to issue in judicial proceedings, the statutory provisions designed to permit expeditious administrative action would be rendered largely nugatory.

These considerations would doubtless have sufficed, in most cases, to dissuade the court from issuing preliminary injunctions even if there were no such statutory prohibition, for it is familiar doctrine that a preliminary injunction restraining governmental action will not be issued if the threatened private injury is outweighed by the possible public injury involved. ${ }^{65}$ The same considerations, buttressed by the deliberate Congressional determination that the public interest in preventing inflation outweighs any hardship that may temporarily be imposed upon individuals, should be sufficient to dispose of the contention that the statutory restrictions upon the issuance of preliminary injunctions constitute a denial of due process. ${ }^{00}$

that there was no judicial power to interfere in the administrative enforcement of the legislative policy. See also Federal Power Comm'n v. Pacific Power \& Light Co., 307 U. S. 156, 160 (1939); Fly v. Heitmeyer, 309 U. S. 146 (1940).

${ }^{\circ}$ See Marconi Wireless Tel. Co. v. Simon, 227 Fed. g06 (S. D. N. Y. 1915); Dryfoos v. Edwards, 284 Fed. 596 (S. D. N. Y. rg19), aff'd, 251 U. S. 264 (1920); Tennessee Valley Authority v. Tennessee Electric Power Co., 90 F. (2d) 885 (C. C. A. 6th, 1937). Mr. Justice Holmes approved this principle in Block v. Hirsh, 256 U. S. 135 (I921), sustaining the World War I District of Columbia rent control law despite the fact that tenants remained in possession at existing rentals pending review. Of particular pertinence is the concurring opinion of Mr. Justice Frankfurter in Mayo v. Lakeland Highlands Canning Co., 309 U. S. 310,319 (1940), in which he denounced the issuance of a temporary injunction to restrain enforcement of the Florida Citrus Fruit Price Control Act.

${ }^{\circ}$ In principle, the Court approved legislative prohibition of interlocutory injunctions in ScrippsHoward v. Federal Communications Comm'n, 62 Sup. Ct. 857 (r942). After examining the legislative history and the enforcement practice the Court refused to sustain the Government's contention that the Communications Act of 1934 prohibited stays of the Commission's orders pending judicial review. Significantly enough the Court referred to the Emergency Price Control Act as having this effect and said, at p. 883, "Where Congress wished to deprive the courts of this historic power, it knew how to use apt words-only once has it done so and in a statute born of the exigencies of war." The same thing was done in another war measure, the National Prohibition Act of I919, 4I STAT. 3II, 27 U. S. C. \$2I. This limitation on judicial interference with revocations of alcohol dealers licenses pending revicw was cnforced in a number of cases. See, e.g., Sparton Mfg. Co. v. Campbell, 40 F. (2d) 745 (E. D. N. Y. 1930).

Cf. Oklahoma Natural Gas Co. v. Russell, 26r U. S. 290 (r923); Pacific Tel. \& Tel. Co. v. Kuykendall, 265 U. S. 196 (1924); Mountain States Power Co. v. Public Service Comm'n, 299 U. S. I67 (1936). These cases are often cited for the proposition that due process requires that temporary relief be available pending judicial review of claims of confiscation in public utility rate cases. Actually none goes so far. The real basis for these decisions was that there was no statutory bar to the issuance of a temporary injunction in the particular case. Clearly, the public utility rate situation must be distinguished from cases arising under this Act in view of the statutory obligation of the utility to continue its service. $C f$. $\S_{4}(\mathrm{~d})$ of the Act expressly denying the existence of any obligation to sell on the part of persons subject to this act.

See also Phillips v. Commissioner of Internal Revenue, 283 U. S. 589 (1931); cf. Halsey, Stuart \& Co. v. Public Service Commission, 212 Wis. 184,248 N. W. 458 (1933). But see Porter v. Investors Syndicate, 286 U. S. 461 (1932). In that case the Court construed a state statute as not prohibiting the issuance of a temporary injunction pending review of the suspension of a broker's license by a Bluc Sky Commission although the Court indicated that a contrary construction would have resulted in a denial of due process. The case raises no serious doubt as to the validity of this act in view of the obvious distinction between a "license suspension," directed at a particular individual and based on a quasi-judicial hearing, and the issuance of general price regulations. 
The same fundamental issues must be faced in determining the validity of the exclusive jurisdiction provisions of the statute. These provisions prohibit any court other than the Emergency Court of Appeals from considering the validity of any regulation or order issued under Section 2 or any price schedule effective in accordance with the provisions of Section 206. They also prohibit any court from issuing an injunction to restrain the enforcement of the statute upon any ground whatsoever. They do not, however, prevent any court in which proceedings are brought for the enforcement of the statute from considering the constitutional validity of the statute itself, as distinguished from any regulations or orders issued thereunder. ${ }^{67}$

These provisions were designed, in part, to overcome the practical difficulties which would prevent effective price control if the validity of the Section 2 regulations or orders could be questioned in enforcement proceedings. Proof and consideration of complicated economic data underlying the validity of the regulations would result in long-drawn-out trials and make speedy and decisive enforcement impossible. ${ }^{68}$ Under such circumstances the expert personnel of the Office of Price Administration would be required to spend a large part of its time testifying in judicial proceedings throughout the country, rather than in making the investigations, studies and analyses which effective administration of the Act requires. Moreover, conflicting decisions with respect to the same regulation would result in unequal application in various parts of the country. Until such conflicts were resolved by the Supreme Court of the United States, effective enforcement would be impossible. In the meanwhile price disparities might have caused fundamental economic dislocations, and individual violations might have developed into general price increases whose inflationary tendencies could never be eradicated.

Constitutional objections to the exclusive jurisdiction provisions could be based only upon the doctrine of the separation of powers or upon the due process clause. In view of the recognized powers of Congress to establish special courts, ${ }^{6 \theta}$ to limit or withdraw the power to issue injunctions, ${ }^{70}$ and to provide for the review of adminis-

\footnotetext{
or The legislative history of the Act requires this construction of the exclusive jurisdiction provision. See Senate Report 25. "Of course, the courts in which criminal or civil enforcement proceedings are brought have jurisdiction, concurrently with the Emergency Court, to determine the constitutional validity of the statute itself."

${ }^{88}$ Compare the experience of the courts in the trial of public utility rate cases. The rate proceeding culminating in Ohio Bell Telephone Co. v. Public Utilities Commission of Ohio, 30r U. S. 292 (r937), consumed I4 years in its various phases. Lindheimer v. Illinois Bell Telephone Co., 292 U. S. 15I (1934), concluded litigation begun in I921. See discussion by Mr. Justice Brandeis in his concurring opinion in St. Joseph Stock Yards Co. v. U. S., 298 U. S. 38, 73 (r936), discussing the length of time consumed in rate litigation. See also-Mr. Justice Black's dissent in MrcCart v. Indianapolis Water Co., 302 U. S. 4I9, 435 (1938), which refers to seven other such cases decided by the Supreme Court which had averaged more than three years of litigation.

${ }^{\circ 0} \mathrm{Sec}$, e.g., the Court of Customs Appeals, 36 STAт. I05 (xg09), 28 U. S. C. \$3ro; and the Commerce Court, created by 36 STAT. II46 (IgII), and abolished by 38 STAT. 2I9 (I9I3), 28 U. S. C. $\$ 4$ I (8).

${ }^{70}$ See Kline v. Burke Construction Co., 260 U. S. 226, 234 (I922). "Only the jurisdiction of the Supreme Court is derived directly from the Constitution. Every other court created by the general government derives its jurisdiction wholly from the authority of Congress. That body may give, withhold or restrict such jurisdiction at its discretion, provided it be not extended beyond the boundaries fixed by the Constitution." Cf. the Norris-LaGuardia Act, 47 STAT. 7I (I932), 29 U. S. C. \$107, limiting the power to issue injunctions in cases arising from labor disputes. See Milk Wagon Drivers' Union Local No. 753 r. Lake Valley Farm Products, Inc., 311 U. S. 9I (I940); Lauf ₹. Shinner \& Co., 303 U. S. 323 (I938);
} 
trative orders in certain courts and their enforcement in others, ${ }^{71}$ the separation of powers argument seems to be entirely lacking in substance. It should also be noted that the "inherent powers" of courts to determine the validity of statutes which they are asked to enforce are in no way restricted by the exclusive jurisdiction provisions. ${ }^{72}$

The contention that the exclusive jurisdiction provisions constitute a denial of due process to the defendant in civil or criminal enforcement proceedings goes to the heart of the procedure provided by the statute. It squarely poses the question of whether it is reasonable for Congress to require that administrative regulations be obeyed while their validity is being tested. The necessity for this provision is substantially the same as the necessity for the provision prohibiting preliminary injunctions. The public interest in preventing inflation is so urgent that it does not permit of delays in the enforcement of price or rent regulations or gaps in their application. In such circumstances, due process does not require that persons subject to price or rent regulations be given an opportunity to gamble on their invalidity. ${ }^{73}$ There is here no attempt to preclude a judicial determination by establishing unusually heavy penalties. ${ }^{74}$ On the contrary, the path has been cleared for a speedy and complete judicial review without any of the risks of disobedience. The exclusive jurisdiction provisions require only that this path be followed. Whether or not such provisions would be appropriate in a peace-time price control measure, with no real threat of inflation impending, is now an academic question. There is no doubt that the exclusive jurisdiction provisions are both appropriate and essential to the effective operation of the Emergency Price Control Act.

Levering \& Garrigues Co. v. Morrin, 7I F. (2d) 284 (C. C. A. 2d, 1934), cert. denied, 293 U. S. 595 (r934). Compare the Johnson Act, 48 Stat. 775 (r934), 28 U. S. C. \$4I(I) (1934), which deprives district courts of jurisdiction over rate orders of state public utility commissions when there is a plain and speedy remedy afforded in the state courts. Injunctions to stay proceeding in state courts are prohibited by 36 StAт. II62 (I9rI), 28 U. S. C. $\$ 379$ (1934), construed in Touccy v. New York Life Insurance Co., 314 U. S. II8 (I94I). Since 1867 , suits to restrain assessment or collection of taxes bave been prohibited. Rev. Stat. \$3224 (I875), 26 U. S. C. \$1543. See 50 Stat. 752 (1937), 28 U. S. C. A. $\$ 380$ (a), which limits power to enjoin enforcement of federal statutes on claim of unconstitutionality to three-judge courts. See also 36 STAT. 557 (x9ro), 28 U. S. C. $\$ 380$, imposing the same limitation with respect to state legislative and administrative action.

${ }^{71}$ Cf. Fair Labor Standards Act of r938, 52 StAT. ro65, 29 U. S. C. A. \$210; Federal Trade Commission Act, 38 Stat. 7 19 (I914), I5 U. S. C. \$45, Agricultural Adjustment Act of I938, 52 StAT. 64, 7 U. S. C. A. $\$ 1367$. See also review of orders of the Interstate Commerce Commission by the procedure set up in the Urgent Deficiencies Act, 38 SrAT. 220 (rgr3), 28 U. S. C. \$47. It also is used for revicw, inter alia, of orders of the Secretary of Agriculture under the Packers and Stockyards Act, 42 STAT. I68 (I92I), 7 U. S. C. $\$ 217,49$ STAT. 649 (1935), 7 U. S. C. A. $\$ 218$ (c); and of certain orders of the Federal Communications Commission under the Communications Act of r934, 48 Stat. ro93, 47 U. S. C. A. $\$ 402(\mathrm{a})$.

${ }^{72}$ See note 67 , supra.

${ }^{73}$ See Bradley v. City of Richmond, 227 U. S. 477 (1913); Bianchi v. Morales, 262 U. S. x70, r71 (I923); cf. U. S. v. R. L. Dixon \& Bro., 36 F. Supp. I47 (N. D. Tex. I940) (a defendant in an action for penalties under the Agricultural Adjustment Act was denied a hearing on the question of the validity of the quota imposed since he had not contested it in the manner prescribed by the Act); U. S. v. Piuma, 40 F. Supp. IIg (S. D. Calif. I94I) (same result in action for penalties for violation of cease and desist order of Federal Trade Commission); Inghram v. Union Stock Yards Co., 64 F. (2d) 390 (C. C. A. 8th, 1933) (same result in action to collect charges approved by Secretary of Agriculture under Packers and Stockyards Act); U. S. v. Vacuum Oil Co., 158 Fed. 536 (W. D. N. Y. 1908) (same result in prosecution of shipper for receiving rebates from carrier who sought to attack reasonableness of violated rate).

${ }^{74}$ Cf. Ex parte Young, 209 U. S. 123 (Ig08). 